\title{
HEAT RECOVERY IN HYBRID FLASH/ORC POWER PLANTS
}

\author{
Andriy Redko ${ }^{1}$, Adam Ujma ${ }^{2}$, Anna Pavlovska ${ }^{1}$, Yurii Burda ${ }^{1}$, Volodymyr Andoniev ${ }^{1}$ \\ ${ }^{1}$ Kharkiv National University of Construction and Architecture, Ukraine; \\ ${ }^{2}$ Czestochowa University of Technology, Poland \\ andrey.ua-mail@ukr.net, adam.ujma@pcz.pl, anuta0067@gmail.com, \\ burda.yurii.1991@gmail.com, andoniev.volodymyr@gmail.com
}

\begin{abstract}
The usage of exhaust gas heat in WHR (Waste Heat Recovery) systems and its conversion into electrical energy using ORC technologies is limited by the thermal stability of working bodies at a temperature of exhaust gases above $270-300^{\circ} \mathrm{C}$. Therefore, thermal schemes of hybrid power plants, in which water vapor and organic heat carriers are used as working fluids, are being developed. Numerous studies indicate that the efficiency of the thermal scheme of energy conversion is significantly influenced by the properties of working bodies and their parameters. Due to the large number of working bodies, the problem of their thermodynamic parameter effect has not been sufficiently studied. This paper [13] presents a review on hybrid renewable energy power generation systems focusing on energy sustainability.
\end{abstract}

Keywords: energy efficiency, biofuel, hybrid installation, hybrid power plant.

\section{Problem state}

Increasing the energy efficiency of agricultural enterprises, including greenhouses, is possible by using cogeneration units of heat pumps of various types of biofuels. The usage of solid biofuels (pellets, briquettes, chips), liquid biofuels (ethanol, methanol, biodiesel), biogas and biohydrogen increases the economic efficiency of agricultural enterprises from $20 \%$ to $25 \%$, as well as improves environmental performance. Many European countries widely use wood waste (Denmark, Sweden, Great Britain, the Netherlands and Germany) for heat supply of enterprises. The largest biofuel producers are the USA (40 million tons) and Brazil (20 million tons).

Biofuel consumption in Poland reaches 10\% [1-4]. The country is dominated by the production of biodiesel from rapeseed oil and ethanol from corn. In Ukraine, biofuel production is 1.923 million tons of oil equivalent, and in Poland it is 518 thousand tons of oil equivalent. Increasing the efficiency of fuel-using units is achieved by using waste gas heat recovery systems and converting it into electrical energy $[4 ; 5]$. The report presents the results of a numerical study of a hybrid power plant in which heat recovery of exhaust gases from internal combustion engines of boiler units and other fuel-using units is provided. The use of the heat of exhaust gases with a temperature from $250{ }^{\circ} \mathrm{C}$ to $350{ }^{\circ} \mathrm{C}$ ensures the generation of electricity, which increases the efficiency of energy supply systems for agricultural enterprises. The hybrid power system consists of three circuits, including an evaporator boiler, a steam separator, a steam turbine and two organic working fluid turbines [6-13].

The energy system (Waste Heat Recovery Systems) works as follows (Fig. 1).

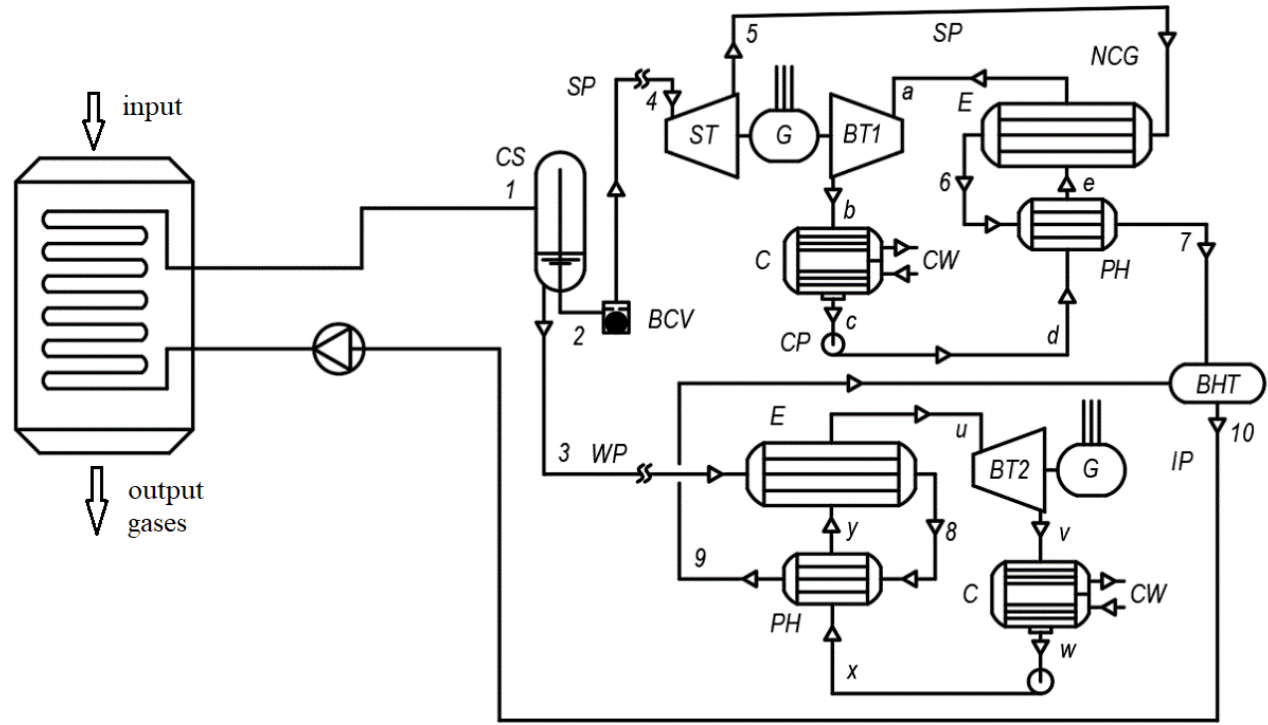

Fig. 1. Schematic diagram of hybrid installation 
Waste gases of the fuel-using unit (boiler, industrial furnace, internal combustion engine) enter the heat recovery boiler, where heat is removed from the gases and transferred to water. The boiler produces wet steam with varying degrees of dryness. Steam enters the separator where saturated steam is generated, and water is separated. Saturated steam is fed to the ST steam turbine, and then to the E evaporator and the $\mathrm{PH}$ recuperator, where it gives off heat to the organic working heat-carrier (Wf) of the second (a-b-c-d-e) circuit. [1-2] The generated steam is fed to the second circuit turbines. The liquid after the separator enters the evaporator $\mathrm{E}$ of the third circuit with organic Wf $(\mathrm{u}-\mathrm{v}-\mathrm{w}-\mathrm{X}-\mathrm{y})$. The organic steam Wf is fed to the third circuit turbine BT2. Thus, the steam turbine ST and the turbines of the organic circuits VT1 and VT2 generate electric power.

\section{Research results and their analysis}

The calculations of thermal circuits have been carried out with the following initial data: efficiency of a steam turbine is 0.85 , efficiency of freon turbines is 0.85 , efficiency of pumps is 0.75 , ambient temperature is $25^{\circ} \mathrm{C}$, under recovery temperature difference is $5 \mathrm{~K}[1-2]$.

\section{Case A}

The research results show that the total generated specific electric power is $511 \mathrm{~kW}$. At the same time, the power of the steam turbine is $286 \mathrm{~kW}$, and the power generated in the second and third circuits, implementing the organic Rankine cycle (ORC), is $253 \mathrm{~kW}$. The efficiency of the hybrid plant is $23.4 \%$. The parameters of the working bodies at the control points of the thermal scheme of the installation are given in Table 1.

Table 1

Parameters of working bodies at control points of the thermal scheme (Case A)

\begin{tabular}{|c|c|c|c|c|c|c|}
\hline No. & $P, \mathrm{kPa}$ & $t,{ }^{\circ} \mathrm{C}$ & $x$ & $s, \mathbf{k J} \cdot(\mathbf{k g} \cdot \mathbf{K})^{-1}$ & $h, \mathbf{k J} \cdot \mathbf{k g}^{-1}$ & $m, \mathrm{~kg} \cdot \mathrm{s}^{-1}$ \\
\hline 1 & 3976 & 250.0 & 0.0 & 2.794 & -14840 & 1.30 \\
\hline 2 & 3976 & 250.0 & 0.5 & 4.433 & -13980 & 1.30 \\
\hline 3 & 3976 & 250.0 & 0.0 & 2.794 & -14840 & 0.65 \\
\hline 4 & 3976 & 250.0 & 1.0 & 6.073 & -13120 & 0.65 \\
\hline 5 & 150 & 11.40 & 0.8504 & 6.359 & -13560 & 0.65 \\
\hline 6 & 150 & 111.40 & 0.2906 & 3.117 & -14810 & 0.65 \\
\hline 7 & 150 & 81.06 & 0.0 & 2.266 & -15140 & 0.65 \\
\hline 8 & 3976 & 132.20 & 0.0 & 1.654 & -15370 & 0.65 \\
\hline 9 & 3976 & 39.63 & 0.0 & 0.5658 & -15760 & 0.65 \\
\hline 10 & 150 & 60.78 & 0.0 & 0.8409 & -15670 & 1.30 \\
\hline $\mathrm{a}$ & 2700 & 106.20 & 1.0 & 2.727 & -7175 & 4.00 \\
\hline $\mathrm{b}$ & 675 & 41.34 & 1.0 & 2.750 & -7216 & 4.00 \\
\hline $\mathrm{c}$ & 675 & 29.32 & 0.0 & 1.788 & -7507 & 4.00 \\
\hline $\mathrm{d}$ & 2700 & 31.00 & 0.0 & 1.790 & -7504 & 4.00 \\
\hline $\mathrm{e}$ & 2700 & 87.49 & 0.0 & 2.167 & -7378 & 4.00 \\
\hline $\mathrm{u}$ & 2700 & 144.9 & 1.0 & 2.702 & -2327 & 1.49 \\
\hline $\mathrm{V}$ & 355 & 76.45 & 1.0 & 2.733 & -2388 & 1.49 \\
\hline $\mathrm{w}$ & 355 & 32.70 & 0.0 & 1.637 & -2731 & 1.49 \\
\hline $\mathrm{x}$ & 2700 & 34.66 & 0.0 & 1.642 & -2727 & 1.49 \\
\hline $\mathrm{y}$ & 2700 & 111.90 & 0.0 & 2.130 & -2557 & 1.49 \\
\hline
\end{tabular}

Note: $P$ - pressure; $t$ - temperature; $x$ - degree of dryness; $s$ - specific heat capacity; $h$ - entropy; $m$ mass flow.

\section{Case B}

The calculations of the thermal circuit of the hybrid power plant have been performed with the same parameters as for CASE A, but the mass flow rate of water vapor is reduced to $m=0.5 \mathrm{~kg} \cdot \mathrm{s}^{-1}$. The calculation results are shown in Table 2. Analysis of the results shows that at a mass flow rate of $0.5 \mathrm{~kg} \cdot \mathrm{s}^{-1}$, a steam temperature is $250^{\circ} \mathrm{C}$ and a steam pressure is $3976 \mathrm{kPa}$, the generated electric power is reduced to $220 \mathrm{~kW}$, and the power of the turbine using R152a is $121.4 \mathrm{~kW}$, and the power of the turbine with $\mathrm{R} 600 \mathrm{a} / \mathrm{R} 141 \mathrm{~b}$ is $69.4 \mathrm{~kW}$. The total generated power is reduced to $391.1 \mathrm{~kW}$, and the efficiency of the thermal circuit is $23.6 \%$. 
The generated electrical power decreases with a decrease in the heat load in the steam generator and a decrease in the mass flow rate of water vapor.

The Case $\mathbf{C}$ variant, in which the steam parameters are changed, namely, the steam mass flow rate is $0.35 \mathrm{~kg} \cdot \mathrm{s}^{-1}$, the steam temperature is $250^{\circ} \mathrm{C}$, and the steam pressure is $3976 \mathrm{kPa}$, is considered as well. The working fluids in the power plant have been changed: in the circuit (a-b-c-d-e), a mixture of $\mathrm{R} 600 \mathrm{a} / \mathrm{R} 141 \mathrm{~b}$ is used, and in the circuit (u-v-w-X-y), R152a is used. The calculation results are shown in Table 3. The steam turbine power is $156.8 \mathrm{~kW}$, the R600a/R141b turbine power is $36 \mathrm{~kW}$, and the $\mathrm{R} 152 \mathrm{a}$ turbine power is $74.4 \mathrm{~kW}$. The total generated power is reduced to $256.1 \mathrm{~kW}$, and the efficiency of the power plant is $19.3 \%$.

Table 2

Parameters of working bodies at control points of the thermal scheme (Case B)

\begin{tabular}{|c|c|c|c|c|c|c|}
\hline No. & $P, \mathrm{kPa}$ & $t,{ }^{\circ} \mathrm{C}$ & $x$ & $s, \mathrm{~kJ} \cdot(\mathrm{kg} \cdot \mathrm{K})^{-1}$ & $h, \mathrm{~kJ} \cdot \mathrm{kg}^{-1}$ & $m, \mathrm{~kg} \cdot \mathrm{s}^{-1}$ \\
\hline 1 & 3976 & 250.0 & 0.0 & 5.561 & -14790 & 1.00 \\
\hline 2 & 3976 & 250.0 & 0.5 & 7.224 & -13920 & 1.00 \\
\hline 3 & 3976 & 250.0 & 0.0 & 5.561 & -14790 & 0.50 \\
\hline 4 & 3976 & 250.0 & 1.0 & 8.887 & -13050 & 0.50 \\
\hline 5 & 150 & 111.4 & 0.8504 & 9.184 & -13510 & 0.50 \\
\hline 6 & 150 & 111.4 & 0.3046 & 8.713 & -13690 & 0.50 \\
\hline 7 & 150 & 108.8 & 0.0 & 4.058 & -15480 & 0.50 \\
\hline 8 & 3976 & 173.8 & 0.0 & 4.763 & -15180 & 0.50 \\
\hline 9 & 3976 & 67.10 & 0.0 & 3.548 & -15660 & 0.50 \\
\hline 10 & 150 & 88.50 & 0.0 & 3.817 & -15570 & 1.00 \\
\hline $\mathrm{a}$ & 2700 & 106.20 & 1.0 & 2.727 & -7175 & 3.00 \\
\hline $\mathrm{b}$ & 675 & 41.34 & 1.0 & 2.75 & -7216 & 3.00 \\
\hline $\mathrm{c}$ & 675 & 29.32 & 0.0 & 1.788 & -7507 & 3.00 \\
\hline $\mathrm{d}$ & 2700 & 31.00 & 0.0 & 1.79 & -7504 & 3.00 \\
\hline $\mathrm{e}$ & 2700 & 88.56 & 0.0 & 2.645 & -7205 & 3.00 \\
\hline $\mathrm{u}$ & 2700 & 144.90 & 1.0 & 2.702 & -2327 & 1.08 \\
\hline $\mathrm{v}$ & 355 & 76.45 & 1.0 & 2.733 & -2388 & 1.08 \\
\hline $\mathrm{W}$ & 355 & 32.70 & 0.0 & 1.637 & -2731 & 1.08 \\
\hline $\mathrm{x}$ & 2700 & 34.66 & 0.0 & 1.642 & -2727 & 1.08 \\
\hline $\mathrm{y}$ & 2700 & 128.80 & 0.0 . & 2.259 & -2506 & 1.08 \\
\hline
\end{tabular}

Parameters of working bodies at control points of thermal scheme (Case C)

Table 3

\begin{tabular}{|c|c|c|c|c|c|c|}
\hline No. & $P, \mathrm{kPa}$ & $t,{ }^{\circ} \mathrm{C}$ & $x$ & $s, \mathrm{~kJ} \cdot(\mathrm{kg} \cdot \mathrm{K})^{-1}$ & $h, \mathrm{~kJ} \cdot \mathrm{kg}^{-1}$ & $m, \mathrm{~kg}^{\prime} \mathrm{s}^{-1}$ \\
\hline 1 & 3976 & 250.0 & 0.0 & 2.794 & -14840 & 1.00 \\
\hline 2 & 3976 & 250.0 & 0.35 & 3.942 & -14240 & 1.00 \\
\hline 3 & 3976 & 250.0 & 0.0 & 2.794 & -14840 & 0.65 \\
\hline 4 & 3976 & 250.0 & 1.0 & 6.073 & -13120 & 0.35 \\
\hline 5 & 140 & 109.30 & 0.8487 & 6.365 & -13570 & 0.35 \\
\hline 6 & 140 & 109.30 & 0.261 & 2.935 & -14880 & 0.35 \\
\hline 7 & 140 & 109.30 & 0.1116 & 2.063 & -15220 & 0.35 \\
\hline 8 & 3976 & 92.00 & 0.0 & 1.213 & -15540 & 0.65 \\
\hline 9 & 3976 & 37.21 & 0.0 & 0.5335 & -15770 & 0.65 \\
\hline 10 & 140 & 83.87 & 0.0 & 1.121 & -15570 & 1.00 \\
\hline $\mathrm{a}$ & 1148 & 99.71 & 1.0 & 2.448 & -2466 & 2.00 \\
\hline $\mathrm{b}$ & 580 & 77.74 & 1.0 & 2.457 & -2484 & 2.00 \\
\hline $\mathrm{c}$ & 580 & 57.37 & 0.0 & 1.653 & -2755 & 2.00 \\
\hline d & 1148 & 57.90 & 0.0 & 1.654 & -2754 & 2.00 \\
\hline
\end{tabular}

Table 3 (continued) 


\begin{tabular}{|c|c|c|c|c|c|c|}
\hline No. & $\boldsymbol{P}, \mathbf{~ k P a}$ & $\boldsymbol{t},{ }^{\mathbf{o}} \mathbf{C}$ & $\boldsymbol{x}$ & $\boldsymbol{s}, \mathbf{k J} \cdot(\mathbf{k g} \cdot \mathbf{K})^{-\mathbf{1}}$ & $\boldsymbol{h , ~} \mathbf{k J} \cdot \mathbf{k g}^{-\mathbf{1}}$ & $\boldsymbol{m}, \mathbf{k g} \cdot \mathbf{s}^{-\mathbf{1}}$ \\
\hline $\mathrm{e}$ & 1148 & 88.56 & 0.0 & 1.823 & -2695 & 2.00 \\
\hline $\mathrm{u}$ & 2700 & 219.00 & 1.0 & 3.127 & -7002 & 1.206 \\
\hline $\mathrm{V}$ & 700 & 163.00 & 1.0 & 3.152 & -7063 & 1.206 \\
\hline $\mathrm{w}$ & 700 & 30.61 & 0.0 & 1.796 & -7504 & 1.206 \\
\hline $\mathrm{X}$ & 2700 & 32.31 & 0.0 & 1.798 & -7501 & 1.206 \\
\hline $\mathrm{y}$ & 2700 & 87.49 & 0.0 & 2.167 & -7378 & 1.206 \\
\hline
\end{tabular}

\section{Conclusions}

As a result of the study, it has been found that the generated electrical power significantly depends on the operating mode of the heat source. Variable modes and loads of hot water supply lead to a decrease in the generated power in the hybrid power plant due to the fact that steam with varying degrees of dryness (from 0.1 to 0.5 ) is generated in the waste heat boiler. At the same time, the generated power varies from $250 \mathrm{~kW}$ to $511 \mathrm{~kW}$.

The influence of the parameters of water vapor in front of the turbine has been established. Changing the steam temperature from $165^{\circ} \mathrm{C}$ to $250^{\circ} \mathrm{C}$, leads to a change in the generated power from $295 \mathrm{~kW}$ to $500 \mathrm{~kW}$. The increase in steam consumption provides an increase in the generated electric power from $15 \%$ to $25 \%$.

\section{References}

[1] Redko A., Redko O., DiPippo R. (2019) Low-Temperature Energy Systems with Applications of Renewable Energy, Academic Press, 394 p.

[2] DiPippo R. (2015) Geothermal Power Plants, Butterworth-Heinemann, 800 p.

[3] Machi E., Astolfi M. (2017) Organic Rankine Cycle (ORC) Power Systems: Technologies and Applica-tions, Wood head Publishing, 698 p.

[4] Gulewicz J., (2020) Nowe perspektywy dla geotermii w Polsce. Monitor rynkowy 30.09.2020

[5] Mróz T., Grabowska W. (2019) Energy and Ecological Evaluation of ORC Based Geothermal CHP Plant in Poland - A Case Study. DOI: 10.20944/preprints201910.0279.v1

[6] Bruscoli L., Fiaschi D., Manfrida G., Tempesti D. (2015) Improving the Environmental Sustainability of Flash Geothermal Power Plants - A Case Study. Sustainability, 7 (11), p. 1526215283, DOI: $10.3390 \cdot \mathrm{s}^{-1} \mathrm{u} 71115262$

[7] Taghaddosi M. (2005) Thermodynamic modeling for Combined ORC and Single - Flash Geothermal Power Plants. Proceeding World Geothermal Congress 2005 Antalya, Turkey, 24-29 April 2005. 5 p.

[8] Kaplam U. (2007) Organic Rankine Cycle Configurations. Proceeding European Geothermal Congress 2007 Unterhaching, Germany, 30 May-1 June. 5 p.

[9] Gong Y., Luo Ch., Ma W., Wu Z. (2010) Thermodynamic Analysis of Geothermal Power Generation Combined Flash System with Binary Cycle. Proceeding World Geothermal Congress 2010 Bali, Indonesia, 25-29 April 2010, 15 p.

[10] El Haj Assad M., Bani-Hani M., Khalil M. (2017) Performance of geothermal power plants (single, dual and binary) to compensate for LHC-CERN power consumption: comparative study. Geotherm Energy, 5, 17, DOI: $10.1186 \cdot \mathrm{s}^{-1} 40517-017-0074-\mathrm{z}$

[11] Jafar Yazdi A. (2017) Investigation of different models of combined parallel flash binary cycles. International Journal of Engineering Sciences \& Research Technology, 6 (2), 9 p. DOI: 10.5281 /zenodo.290127

[12] Tomasini-Montenegro C., Santoyo-Castelazo E., Gujba H., Romero R., Santoyo E. (2017) Life cycle assessment of geothermal power generation technologies: An update review. Applied Thermal Engineering, vol. 114, 5 March 2017, p. 1119-1136,

DOI: 10.1016/j.applthermaleng.2016.10.074

[13] Manhas N., Yadav G. D. (2016) A Review on Configurations, Control, and Future of Hybrid Renewable Energy Systems for Electric Power Generation.- International Research Journal of Engineering and Technology (IRJET), vol. 3, issue 6 